\title{
Hubungan Kecerdasan Emosional Dan Kecerdasan Spiritual Terhadap \\ Prestasi Belajar Siswa Pada Mata Pelajaran Fiqih \\ di MA NW Keruak Lombok Timur
}

\author{
Oleh \\ Saprudin Efendi
}

\begin{abstract}
Abstrak
Dalam penelitian ini diajukan 3 (tiga) hipotesis, yaitu terdapat hubungan antara kecerdasan emosional dengan prestasi belajar Fiqih, terdapat hubungan antara kecerdasan spiritual dengan prestasi belajar Fiqih, dan terdapat hubungan antara kecerdasan emosional dan kecerdasan spiritual siswa secara bersama-sama (simultan) dengan prestasi belajar Fiqih siswa.

Sebanyak 60 siswa (30\%), dipilih dari 200 siswa dengan sampel random menjadi sampel penelitian ini. Untuk membantu proses pengumpulan data telah digunakan alat pengumpul data berupa tes, angket, dan dokumentasi. Selanjutnya, data terkumpul dianaisis dengan menggunakan teknik analisis regresi, baik regresi sederhana maupun ganda.

Hasil analisis menunjukkan bahwa: (1) Persamaan $Y^{\prime}=a+b X$ adalah $Y^{\prime}=$ $56.80+0.20 \mathrm{X}_{1}$. Sementara nilai $\mathrm{F}=4.13$, karena itu hipotesis nol (H0) ditolak, dengan hipotesis alternatif (Ha) diterima, pada $\alpha=0.05$. Hal ini berarti bahwa terdapat hubungan positif yang signifikan antara kecerdasan emosional dan prestasi belajar Fiqih siswa. Artinya setiap terjadi variasi yang kearah positif (naik) dari kecerdasan emosional, akan menyebabkan kenaikan (positif) pada variabel prestasi belajar Fiqih siswa, biarpun kekuatan determinasinya hanya sebesar 6.6\%. (2) Persamaan $Y^{\prime}=a+b X_{2}$ adalah $Y^{\prime}=88.80+-0.27 \mathrm{X}_{2}$. Sementara nilai $\mathrm{F}=4.01$, karena itu hipotesis nol (H0) ditolak, dengan hipotesis alternatif (Ha) diterima, pada $\alpha=0.05$. Hal ini berarti bahwa terdapat hubungan positif yang signifikan antara kecerdasan spiritual dan prestasi belajar Fiqih siswa. Artinya, setiap terjadi variasi yang kearah positif (naik) dari kecerdasan intelektual, akan menyebabkan kenaikan (positif) pada variabel prestasi belajar Fiqih siswa, biarpun kekuatan determinasinya hanya sebesar 6.5\%. (3) Analisis regesi ganda dengan persamaan $Y^{\prime}=a+b_{1} X_{1}+$ $b_{2} X_{2}$, adalah $Y^{\prime}=73.06+0.23 \mathrm{X}_{1}+(-0.27) \mathrm{X}_{2}$. Sementara nilai $\mathrm{F}=4.490$, karena itu hipotesis nol (H0) ditolak, dengan hipotesis alternatif (Ha) diterima, pada $\alpha=$ 0.05. Artinya untuk setiap kenaikan 1 unit satuan motivasi belajar siswa $\left(\mathrm{X}_{1}\right)$ dan kecerdasan emosional siswa $\left(\mathrm{X}_{1}\right)$ akan diikuti kenaikan prestasi belajar PAI siswa (Y) sebesar 0.23 pada variabel motivasi belajar siswa dan -0.27 pada variabel kecerdasan spiritual $\left(\mathrm{X}_{2}\right)$ pada bilangan konstan 73.06. Hal ini berarti bahwa terdapat hubungan positif yang signifikan antara motivasi belajar dan kescerdasan intelektual secara bersama-sama terhadap prestasi PAI siswa, biarpun kekuatan determinasinya hanya sebesar $13.6 \%$.
\end{abstract}


Dengan kata lain, kedua variabel (kecerdasan emosional dan kecerdasan spiritual siswa) saling berinteraksi dan mempengaruhi pada variabel prestasi belajar Fiqih siswa. Oleh karena itu, kecerdasan emosional dan kecerdasan spiritual siswa, sangat diperlukan perhatian yang serius, sebagai upaya peningkatan prestasi belajar Fiqih siswa MA NW Keruak Lombok Timur.

Kata kunci: Kecerdasan Emosional, Spiritual, Prestasi Belajar, dan mata pelajaran fiqih

\section{A. Pendahuluan}

Proses belajar yang terjadi pada individu memang merupakan sesuatu yang penting, karena melalui belajar individu mengenal lingkungannya dan menyesuaikan diri dengan lingkungan disekitarnya. Menurut Irwanto, belajar merupakan proses perubahan dari belum mampu menjadi mampu dan terjadi dalam jangka waktu tertentu. Dengan belajar, siswa dapat mewujudkan cita-cita yang diharapkan. ${ }^{1}$

Belajar akan menghasilkan perubahan-perubahan dalam diri seseorang. Untuk mengetahui sampai seberapa jauh perubahan yang terjadi, perlu adanya penilaian. Begitu juga dengan yang terjadi pada seorang siswa yang mengikuti suatu pendidikan selalu diadakan penilaian dari hasil belajarnya. Penilaian terhadap hasil belajar seorang siswa untuk mengetahui sejauh mana telah mencapai sasaran belajar inilah yang disebut sebagai prestasi belajar.

Prestasi belajar menurut Murjono adalah: “ Hasil yang dicapai seorang siswa dalam usaha belajarnya sebagaimana dicantumkan di dalam nilai rapornya. Melalui prestasi belajar seorang siswa dapat mengetahui kemajuan-kemajuan yang telah dicapainya dalam belajar."2

Proses belajar di sekolah adalah proses yang sifatnya kompleks dan menyeluruh. Banyak orang yang berpendapat bahwa untuk meraih prestasi yang tinggi dalam belajar, seseorang harus memiliki Intelligence Quotient (IQ) yang tinggi, karena inteligensi merupakan bekal potensial yang akan memudahkan dalam belajar dan pada gilirannya akan menghasilkan prestasi belajar yang

\footnotetext{
${ }^{1}$ Irwanto. 1997. Psikologi Umum. Jakarta : PT. Gramedia Pustaka Utama, hlm. 105.

${ }^{2}$ Murjono, 1996, Pengantar Umum Psikologi, Cet. VII. Jakarta: Bulan Bintang, hlm. 40
} 
optimal. Menurut Binet dalam buku Winkel ${ }^{3}$ hakikat inteligensi adalah kemampuan untuk menetapkan dan mempertahankan suatu tujuan, untuk mengadakan penyesuaian dalam rangka mencapai tujuan itu, dan untuk menilai keadaan diri secara kritis dan objektif.

Menurut Goleman ${ }^{4}$, kecerdasan intelektual (IQ) hanya menyumbang $20 \%$ bagi kesuksesan, sedangkan $80 \%$ adalah sumbangan faktor kekuatan-kekuatan lain, diantaranya adalah kecerdasan emosional atau Emotional Quotient (EQ) yakni kemampuan memotivasi diri sendiri, mengatasi frustasi, mengontrol desakan hati, mengatur suasana hati (mood), berempati serta kemampuan bekerja sama.

Dalam proses belajar siswa, kedua inteligensi itu sangat diperlukan. IQ tidak dapat berfungsi dengan baik tanpa partisipasi penghayatan emosional terhadap mata pelajaran yang disampaikan di sekolah. Namun biasanya kedua inteligensi itu saling melengkapi. Keseimbangan antara IQ dan EQ merupakan kunci keberhasilan belajar siswa di sekolah. Pendidikan di sekolah bukan hanya perlu mengembangkan rational intelligence yaitu model pemahaman yang lazimnya dipahami siswa saja, melainkan juga perlu mengembangkan emotional intelligence siswa. $^{5}$

Selain IQ dan EQ, SQ memiliki peran yang penting dalam kehidupan manusia. Sebagaimana halnya EQ, SQ juga merupakan hasil kerja elaboratif temuan-temuan bidang neurologi dan psikologi. Freud membagi proses psikologis menjadi 2 (dua) yaitu proses primer dan proses sekunder. Proses primer diasosiasikan dengan EQ dan proses sekunder diasosiasikan dengan IQ. EQ mencermikan jaringan asosiatif syaraf otak dan IQ mencerminkan jaringan serial syaraf otak. Proses primer dan sekunder saling berebut kendali dan ekspresi, oleh karenanya terjadi persaingan antara keduanya.

\footnotetext{
${ }^{3}$ Winkel, WS 1997. Psikologi Pendidikan dan Evaluasi Belajar. Jakarta : Gramedia, hlm. 529

${ }^{4}$ Goleman, Daniel. 2000. Emitional Intelligence (terjemahan). Jakata : PT Gramedia Pustaka Utama, hlm. 44

${ }^{5}$ Gottman, John. 2001. Kiat-kiat Membesarkan Anak yang Memiliki Kecerdasan Emosional (terjemahan). Jakarta : PT Gramedia Pustaka Utama.
} 
Sedangkan SQ ditengarai sebagai proses psikologi yang ketiga dan didasarkan pada sistem syaraf otak ketiga, yakni osilasi-syaraf sinkron yang menyatukan data di seluruh bagian otak. SQ memfasilitasi dialog antara IQ dan EQ sebagaimana yang disebutkan oleh Zohar dan Marshall bahwa SQ merupakan kecerdasan untuk menghadapi dan memecahkan persoalan makna dan nilai hidup, menempatkan perilaku dalam konteks makna secara lebih luas dan kaya. SQ merupakan prasyarat bagi berfungsinya IQ dan SQ secara efektif. ${ }^{6}$

Perbedaan Otak IQ, EQ dan SQ Penelusuran kecerdasan spiritual tampaknya merupakan jawaban akan keterbatasan kemampuan intelektual (IQ) dan emosional (EQ) dalam menyelesaikan kasus-kasus yang didasarkan atas krisis makna hidup. Otak IQ dasar kerjanya adalah berfikir seri, linear, logis dan tidak melibatkan perasaan. Keunggulan dari berfikir seri ini adalah akurat, tepat dan dapat dipercaya. Kelemahannya adalah ia hanya bekerja dalam batas-batas yang ditentukan, dan menjadi tidak berguna jika seseorang ingin menggali wawasan baru atau berurusan dengan hal-hal yang terduga. Otak EQ cara kerjanya berfikir asosiatif. Jenis pemikiran ini membantu seseorang menciptakan asosiasi antar hal, misalnya antara lapar dan nasi, antara rumah dan kenyamanan, antara ibu dan cinta, dan sebagainya..

\section{B. Kajian Teori}

\section{Kecerdasan Emosional}

Istilah "kecerdasan emosional" pertama kali dilontarkan pada tahun 1990 oleh psikolog Peter Salovey dari Harvard University dan John Mayer dari University of New Hampshire untuk menerangkan kualitas-kualitas emosional yang tampaknya penting bagi keberhasilan. Salovey dan Mayer mendefinisikan kecerdasan emosional atau yang sering disebut EQ sebagai :

"himpunan bagian dari kecerdasan sosial yang melibatkan kemampuan memantau perasaan sosial yang melibatkan kemampuan pada orang lain,

\footnotetext{
${ }^{6}$ Ary Ginanjar Agustian, Rahasia Sukses Membangun Kecerdasan Emosi dan Spiritual ESQ Emotional Spiritual Quotient Berdasarkan 6 Rukun Iman dan 5 Rukun Islam, (Jakarta : Arga Wijaya Persada, 2001), hlm . xxi.
} 
memilah-milah semuanya dan menggunakan informasi ini untuk membimbing pikiran dan tindakan.”

Kecerdasan emosional sangat dipengaruhi oleh lingkungan, tidak bersifat menetap, dapat berubah-ubah setiap saat. Untuk itu peranan lingkungan terutama orang tua pada masa kanak-kanak sangat mempengaruhi dalam pembentukan kecerdasan emosional. Keterampilan EQ bukanlah lawan keterampilan IQ atau keterampilan kognitif, namun keduanya berinteraksi secara dinamis, baik pada tingkatan konseptual maupun di dunia nyata. Selain itu, EQ tidak begitu dipengaruhi oleh faktor keturunan. ${ }^{7}$ Sebuah model pelopor lain tentang kecerdasan emosional diajukan oleh Bar-On pada tahun 1992 seorang ahli psikologi Israel, yang mendefinisikan kecerdasan emosional sebagai serangkaian kemampuan pribadi, emosi dan sosial yang mempengaruhi kemampuan seseorang untuk berhasil dalam mengatasi tututan dan tekanan lingkungan. ${ }^{8}$

Menurut Goleman ${ }^{9}$, kecerdasan emosional adalah kemampuan seseorang mengatur kehidupan emosinya dengan inteligensi (to manage our emotional life with intelligence); menjaga keselarasan emosi dan pengungkapannya (the appropriateness of emotion and its expression) melalui keterampilan kesadaran diri, pengendalian diri, motivasi diri, empati dan keterampilan sosial.

Dalam penelitian ini yang dimaksud dengan kecerdasan emosional adalah kemampuan siswa untuk mengenali emosi diri, mengelola emosi diri, memotivasi diri sendiri, mengenali emosi orang lain (empati) dan kemampuan untuk membina hubungan (kerjasama) dengan orang lain. Atau dengan kata lain kecerdasan emosional/Emotional Quotient (EQ) yakni kemampuan seseorang untuk memantau dan mengendalikan perasaan sendiri dan orang lain, serta menggunakan perasaan-perasaan itu untuk memandu pikiran dan tindakan ke arah yang positif.

\footnotetext{
${ }^{7} \mathrm{Ibid}, \mathrm{hlm} .10$

${ }^{8}$ Goleman, 2000, Ibid. 180

${ }^{9}$ Goleman, 2002, Op.Cit. hlm. 512
} 
Di tengah semakin ketatnya persaingan di dunia pendidikan dewasa ini, merupakan hal yang wajar apabila para siswa sering khawatir akan mengalami kegagalan atau ketidak berhasilan dalam meraih prestasi belajar atau bahkan takut tinggal kelas.

Banyak usaha yang dilakukan oleh para siswa untuk meraih prestasi belajar agar menjadi yang terbaik seperti mengikuti bimbingan belajar. Usaha semacam itu jelas positif, namun masih ada faktor lain yang tidak kalah pentingnya dalam mencapai keberhasilan selain kecerdasan ataupun kecakapan intelektual, faktor tersebut adalah kecerdasan emosional.

Karena kecerdasan intelektual saja tidak memberikan persiapan bagi individu untuk menghadapi gejolak, kesempatan ataupun kesulitan-kesulitan dan kehidupan. Dengan kecerdasan emosional, individu mampu mengetahui dan menanggapi perasaan mereka sendiri dengan baik dan mampu membaca dan menghadapi perasaan-perasaan orang lain dengan efektif. Individu dengan keterampilan emosional yang berkembang baik berarti kemungkinan besar ia akan berhasil dalam kehidupan dan memiliki motivasi untuk berprestasi.

Sedangkan individu yang tidak dapat menahan kendali atas kehidupan emosionalnya akan mengalami pertarungan batin yang merusak kemampuannya untuk memusatkan perhatian pada tugas-tugasnya dan memiliki pikiran yang jernih.

Sebuah laporan dari National Center for Clinical Infant Programs (1992) menyatakan bahwa keberhasilan di sekolah bukan diramalkan oleh kumpulan fakta seorang siswa atau kemampuan dininya untuk membaca, melainkan oleh ukuran-ukuran emosional dan sosial: yakni pada diri sendiri dan mempunyai minat; tahu pola perilaku yang diharapkan orang lain dan bagaimana mengendalikan dorongan hati untuk berbuat nakal; mampu menunggu, mengikuti petunjuk dan mengacu pada guru untuk mencari bantuan; serta mengungkapkan kebutuhan-kebutuhan saat bergaul dengan siswa lain. Hampir semua siswa yang prestasi sekolahnya buruk, menurut laporan tersebut, tidak memiliki satu atau lebih unsur-unsur kecerdasan 
emosional ini (tanpa memperdulikan apakah mereka juga mempunyai kesulitan-kesulitan kognitif seperti kertidakmampuan belajar). ${ }^{10}$

\section{Kecerdasan Spiritual}

Pada awal abad kedua puluh, kecerdasan intelektual atau IQ pernah menjadi isu besar, IQ adalah kecerdasan yang digunakan memecahkan masalah logika maupun strategis. Para psikolog menyusun berbagai tes untuk mengukurnya dan tes-tes ini menjadi alat memilah manusia ke dalam berbagai tingkatan kecerdasan. Pada pertengahan 1990-an, Daniel Goleman mempopulerkan penelitian dari banyak neurolog dan psikolog yang menunjukkan bahwa kecerdasan emosional/EQ sama pentingnya dengan kecerdasan intelektual. EQ memberikan kesadaran mengenai perasaan milik diri sendiri dan juga perasaan orang lain. EQ memberikan rasa empati, cinta, motivasi dan kemampuan untuk menanggapi kesedihan atau kegembiraan secara tepat. EQ merupakan persyaratan dasar untuk menggunakan IQ secara efektif. ${ }^{11}$

Secara harfiah SQ beroperasi dari pusat otak yaitu dari fungsi dan penyatu otak. SQ mengintegrasikan semua kecerdasan seseorang dan menjadikannya benarbenar dan utuh secara intelektual, emosional dan spiritual. Idealnya, ketiga kecerdasan dasar seseorang tersebut bekerja sama dan saling mendukung. Otak dirancang agar mampu melakukan hal itu. Meskipun demikian, mereka masingmasing IQ, EQ dan SQ memiliki wilayah kekuatan tersendiri dan bisa berfungsi secara terpisah.

Kebutuhan ber-Tuhan atau memiliki spiritualitas merupakan kebutuhan tak terelakkan pada manusia. Ada kaitan langsung dan tegas antara kebutuhan itu dan tersedianya potensi ke-Tuhanan dalam otak manusia. Para peneliti otak antara lain Universitas California San Diego menemukan daerah temporal sebagai lokasi yang berperan penting dalam perasaan dan spiritual dan mistis. Dengan pantauan EEG (alat perekam gelombang otak) tampak jelas gelombang yang khas ketika seseorang mengalami perasaan mistis dan spiritual tersebut. ${ }^{12}$

\footnotetext{
${ }^{10}$ Goleman, 2002, Ibid. HIm. 273

${ }^{11}$ Danah Zohar \& lan Marshall, 2000, SQ: Memanfaatkan Kecerdasan Spiritual dalam Berpikir Integralistik dan Holistik untuk Memaknai Kehidupan, (Bandung : Mizan Media Utama, hlm. 3

12 Taufiq Pasiak, 2002, Revolusi IQ / EQ /SQ Antara Neurosains dan Al-Qur'an, .(Bandung: Mizan Pustaka,hlm. 275
} 
Saat ini, serangkaian data ilmiah terbaru, yang sejauh ini belum banyak dibahas, menunjukkan adanya kecerdasan jenis ketiga yaitu kecerdasan spiritual. Spiritual dalam bahasa Inggris berasal dari kata "spirit" yang berarti bathin, rokhani, dan keagamaan. ${ }^{13}$ Sedangkan dalam kamus psikologi, spiritual diartikan "sebagai sesuatu mengenai nilai-nilai transcendental". Makna spiritual sendiri berhubungan erat dengan eksistensi manusia dalam dunia ini dan spiritual itu sendiri pada dasarnya mengacu pada bentuk-bentuk keberagaman seseorang yang dibangun dari pengalaman dan spiritual arti hidup, Tuhan dan pandangan-pandangan hidup. ${ }^{14}$

Zohar dan Marshall ${ }^{15}$ berpendapat bahwa kecerdasan spiritual (SQ) adalah kecerdasan untuk menghadapi dan memecahkan persoalan makna dan nilai yaitu kecerdasan untuk menempatkan perilaku dan hidup seseorang dalam konteks makna yang lebih luas dan kaya. Kecerdasan untuk menilai bahwa tindakan atau jalan hidup seseorang lebih bermakna dibandingkan dengan yang lain. SQ adalah landasan yang diperlukan untuk memfungsikan IQ dan EQ secara efektif. SQ secara harfiah untuk menumbuhkan otak manusia. Dengan SQ manusia dapat menggali potensi yang dimilikinya untuk tumbuh dan berubah serta menjalankan lebih lanjut evolusi potensi yang dimilikinya.

SQ memungkinkan seseorang untuk menyatukan hal-hal yang bersifat intrapersonal dan interpersonal, serta menjembatani kesenjangan antara diri dan orang lain. Daniel Goleman telah menulis tentang emosi-emosi intrapersonal di dalam diri seseorang yang digunakan untuk berhubungan dengan orang lain. Namun EQ semata-mata tidak dapat membantu seseorang mempunyai pemahaman tentang siapa dirinya dan apa makna segala sesuatu baginya, dan bagaimana semua itu memberikan suatu tempat di dalam dunianya kepada orang lain.

Kecerdasan spiritual mengajak dan bahkan membimbing seseorang menjadi diri yang geniune, yang asli dan autentik yang karenanya selalu mengalami harmoni ilahi kehadirat Rabbi. Pengalaman harmoni spiritual kehadirat Tuhan dicapai dan sekaligus dirasakan dengan menggunakan apa yang dalam mistik spiritual disebut

\footnotetext{
${ }^{13}$ Echol, M Jhon dan Hasan Sadily, 1992, Kamus Inggris-Indonesia, Jakarta: Gramedia, hlm 546.

${ }^{14}$ M. Hafidz Anshori, 1995, Kamus Psikologi, Surabaya : Usaha Kanisius, hlm. 653

${ }^{15}$ Zohar dan Marshall , Op. Cit., 12
} 
sebagai mata hati. ${ }^{16} \mathrm{SQ}$ menyelami semua itu sebagai mata hati, karena mata hati dapat menyingkap kebenaran hakiki yang tak tampak oleh mata. Sebagaimana firman Allah dalam Qur'an Surat As Sajdah ayat: 9.

Artinya: "Kemudian ia memberinya bentuk (dengan perbandingan ukuran yang baik) dan meniupkan ke dalam ruh (ciptaan) Nya. Kejadian bagi kamu pandangan, penglihatan, dan perasaan hati." (QS: As-Sajdah: 9).

Spiritual intelligence adalah kemampuan seseorang untuk mendengarkan hati nuraninya atau bisikan kebenaran yang meng-llahi dalam cara dirinya mengambil keputusan atau melakukan pilihan-pilihan, berempati dan beradaptasi. Untuk itu kecerdasan spiritual sangat ditentukan oleh upaya untuk membersihkan dan memberikan pencerahan qalbu sehingga mampu memberikan nasihat dan arah tindakan serta caranya mengambil keputusan. Qalbu harus senantiasa berada pada posisi menerima curahan cahaya nur yang bemuatan kebenaran dan kecintaan kepada llahi. ${ }^{17}$

Kecerdasan intelektual (IQ) dapat dihubungkan dengan kecerdasan akal pikiran ('aql), sementara kecerdasan emosional (EQ) lebih dihubungkan dengan emosi diri (nafs), dan kecerdasan spiritual mengacu pada kecerdasan hati, jiwa atau disebut dengan qalb ${ }^{18}$ sebagaimana firman Allah dalam QS. Ar-rad ayat 28:

Artinya: "(yaitu) orang-orang yang beriman dan hati mereka manjadi tenteram dengan mengingat Allah. Ingatlah, Hanya dengan mengingati Allah-lah hati menjadi tenteram."

Sadar atau tidak, potensi kecerdasan intelektual, emosional dan spiritual itu ada dalam keseluruhan diri seseorang sebagai manusia. Kecerdasan intelektual (IQ) berada di wilayah otak yang karenanya terkait dengan kecerdasan otak, rasio, nalar intelektual, kecerdasan emotional (EQ) mengambil wilayah di sekitar emosi diri seseorang yang karenanya lebih mengembangkan emosi supaya cerdas, tidak cenderung marah, sedangkan kecerdasan spiritual (SQ) mengambil tempat seputar

\footnotetext{
${ }^{16}$ Sukidi, 2002, Rahasia Sukses Hidup Bahagia, Kecerdasan Spiritual, Mengapa SQ Lebih Penting Daripada IQ \& SQ, Jakarta: PT. Gramedia Pustaka Umum, 327

${ }^{17}$ Toto Tasmara, 2001, Kecerdasan Ruhaniyah : Transendental Intelligence, Jakarta: Gema Insani Press.

${ }^{18}$ Departemen Agama, 2000, Al Qur'an \& Terjemahannya, Semarang : CV. Toha Putra, hlm. 373
} 
jiwa, hati yang merupakan wilayah spirit yang karenanya dikenal dengan The Souls Intelligence, kecerdasan hati yang menjadi hakikat sejati kecerdasan spiritual.

Manusia sejak lahir telah memiliki jiwa spiritual atau naluri keagamaan untuk mengenal Tuhan. Fitrah manusia yang dibawa sejak lahir ini berupa fitrah ketauhidan. Sebagaimana firman Allah dalam QS. Al-A'raf ayat 172 :

"Dan (ingatlah) ketika Tuhanmu mengeluarkan keturunan Adam dari Sulbi mereka dan Allah mengambil kesaksian terhadap diri mereka (seraya berfirman) bukankah aku ini Tuhanmu ? mereka menjawab, benar, (Engkaulah Tuhan kami), kami menjadi saksi (kami lakukan yang demikian itu agar disadari kiamat kami tidak mengatakan : Sesungguhnya kami (bani Adam) orang-orang yang lengah terhadap ini (keesaan Tuhan)." (Al-A'raf: 172).

Sedangkan di dalam ESQ, kecerdasan spiritual adalah kemampuan untuk memberi makna ibadah terhadap setiap perilaku dan kegiatan, melalui langkahlangkah dan pemikiran yang bersifat fitrah, menuju manusia yang seutuhnya dan memiliki pemikiran tauhid serta berprinsip hanya karena Allah SWT.

Memahami kecerdasan spiritual dalam bingkai seperti ini membuat seseorang dengan mudah menemukan nilai-nilai dan makna dari setiap aktivitas yang dilakukannya salah satu ciri SQ adalah kemampuan manusia untuk mengenali potensi, fitrah dalam dirinya. Fitrah adalah akar ilahiyah yang Allah berikan sejak ditiupkan-Nya ruh ke dalam rahim ibu. SQ adalah kemampuan seseorang untuk mengenali dan mendekatkan diri kepada Allah SWT yang telah menciptakan manusia dari segumpal darah. Dengan mengenal Allah seorang manusia niscaya akan mengalami sukses dalam hidupnya bukan hanya di dunia saja tetapi juga di akhirat ia akan mengawali segalanya sesuai dengan perintah Allah SWT.

\section{Prestasi Belajar}

Penilaian terhadap hasil belajar siswa untuk mengetahui sejauhmana ia telah mencapai sasaran belajar inilah yang disebut sebagai prestasi belajar. Seperti yang dikatakan oleh Winkel ${ }^{19}$ bahwa proses belajar yang dialami oleh siswa menghasilkan perubahan-perubahan dalam bidang pengetahuan dan

${ }^{19}$ Winkel, Op. Cit., hlm. 168 
pemahaman, dalam bidang nilai, sikap dan keterampilan. Adanya perubahan tersebut tampak dalam prestasi belajar yang dihasilkan oleh siswa terhadap pertanyaan, persoalan atau tugas yang diberikan oleh guru. Melalui prestasi belajar siswa dapat mengetahui kemajuan-kemajuan yang telah dicapainya dalam belajar.

Sedangkan Marsun dan Martaniah dalam Sia Tjundjing berpendapat bahwa prestasi belajar merupakan hasil kegiatan belajar, yaitu sejauh mana peserta didik menguasai bahan pelajaran yang diajarkan, yang diikuti oleh munculnya perasaan puas bahwa ia telah melakukan sesuatu dengan baik. Hal ini berarti prestasi belajar hanya bisa diketahui jika telah dilakukan penilaian terhadap hasil belajar siswa. ${ }^{20}$

\section{Pembelajaran Fiqih Madrasah Aliyah}

\section{a. Kurikulum Fiqih MA}

Mata pelajaran Fiqih dalam Kurikulum Madrasah Aliyah adalah salah satu bagian mata pelajaran Pendidikan Agama Islam yang diarahkan untuk menyiapkan peserta didik untuk mengenal, memahami, menghayati dan mengamalkan hukum Islam yang kemudian menjadi dasar pandangan hidupnya (way of life) melalui kegiatan bimbingan, pengajaran, latihan penggunaan, pengamalan dan pembiasaan. Mata pelajaran Fiqih Madrasah Aliyah ini meliputi: Fiqih Ibadah, Fiqih Muamalah, Fiqih Jinayat dan Fiqih Siyasah yang menggambarkan bahwa ruang lingkup Fiqih mencakup perwujudan keserasian, keselarasan, dan keseimbangan hubungan manusia dengan Allah SWT., dengan diri sendiri, sesama manusia, makhluk lainnya, maupun lingkungannya (hablunminallah wa hablun minannaas).

\section{b. Tujuan dan Fungsi Pembelajaran Fiqih MA}

Pembelajaran Fiqih di Madrasah Aliyah bertujuan untuk membekali peserta didik agar dapat: (1) mengetahui dan memahami pokok-pokok hukum Islam secara terperinci dan menyeluruh, baik berupa dalil naqli dan aqli.

\footnotetext{
${ }^{20}$ Sia Tjundjing (2000:71) Sia, Tjundjing. 2001. Hubungan Antara IQ, EQ, dan QA dengan Prestasi Studi Pada Siswa SMU. Jurnal Anima Vol.17 no.1
} 
Pengetahuan dan pemahaman tersebut diharapkan menjadi pedoman hidup dalam kehidupan dan sosial. (2) Melaksanakan dan mengamalkan ketentuan hukum Islam dengan benar. Pengalaman tersebut diharapkan menumbuhkan ketaatan menjalankan hukum Islam, disiplin dan tanggung jawab sosial yang tinggi dalam kehidupan pribadi maupun social. Sedangkn pembelajaran Fiqih di Madrasah Aliyah berfungsi untuk:

(a) Penanaman nilai-nilai dan kesadaran beribadah peserta didik kepada Allah Swt. sebagai pedoman mencapai kebahagiaan hidup di dunia dan akhirat;

(b) Penanaman kebiasaan melaksanakan hukum Islam di kalangan peserta didik dengan ikhlas dan perilaku yang sesuai dengan peraturan yang berlaku di madrasah dan masyarakat;

(c) Pembentukan kedisiplinan dan rasa tanggung jawab sosial di Madrasah dan masyarakat;

(d) Pengembangan keimanan dan ketaqwaan kepada Allah. Swt. serta akhlaq mulia peserta didik seoptimal mungkin, melanjutkan yang telah ditanamkan lebih dahulu dalam lingkungan keluarga;

(e) Pembangunan mental peserta didik terhadap lingkungan fisik dan sosial melalui ibadah dan muamalah;

(f) Perbaikan kesalahan-kesalahan, kelemahan-kelemahan peserta didik dalam keyakinan dan pelaksanaan ibadah dalam kehidupan sehari-hari;

(g) Pembekalan peserta didik untuk mendalami Fiqih/hukum Islam pada jenjang pendidikan yang lebih tinggi. ${ }^{21}$

\section{Metode Penelitian}

Populasi dalam penelitian ini adalah seluruh siswa MA NW Keruak subyek di dalam populasi benar-benar homogen". Dari keseluruhan populasi tersebut kemudian diambil sebagiannya untuk dijadikan sampel penelitian, yakni

${ }^{21}$ BSNP, Ibid., 147. 
siswa kelas X MA NW Keruak yang berjumlah 30 siswa (20\% dari jumlah populasi) tahun pelajaran 2018/2019.

Beralasan para siswa MA NW Keruak, mereka rata-rata memiliki umur yang hampir sama, kecerdasan yang hampir sama, latar belakang keluarga, ekonomi, sosial yang sama (Homogen) dan sebagainya, maka dalam penelitian ini penulis menggunakan pengambilan sampel secara Simple Random Sampling. Dikatakan simple (sederhana) karena pengambilan anggota sampel dari populasi dilakukan secara acak tanpa memperhatikan strata yang ada dalam populasi.

Metode yang digunakan dalam pengumpulan data terdiri dari angket, wawancara, dokumentasi dan tes. Sedangkan tehnik analisis data dalam penelitian ini adalah menggunakan teknik analisis statistik deskriptif dan analisis regresi.

Tujuan penelitian ini adalah untuk menguji apakah ada hubungan antara kecerdasan emosional/EQ dan prestasi belajar Fiqih siswa, hubungan antara kecerdasan Spiritual/SQ dan prestasi belajar Fiqih siswa, serta hubungan antara kecerdasan emosional/EQ dan kecerdasan Spiritual/SQ secara bersama-sama terhadap prestasi belajar Fiqih siswa MA NW Keruak tahun pelajaran 2018/2019.

Sedangkan hipotesis yang diajukan dalam penelitian ini adalah:

1. Terdapat hubungan antara kecerdasan emosional dengan prestasi belajar Fiqih siswa

2. Terdapat hubungan antara kecerdasan spiritual dengan prestasi belajar Fiqih siswa

3. Terdapat hubungan antara kecerdasan emosional dan kecerdasan spiritual secara bersama-sama dengan prestasi belajar Fiqih siswa.

Sesuai hipotesis yang diajukan dalam penelitian ini, akan digunakan persamaan regresi. Adapun regresi yang dipakai dalam menguji hipotesis assosiatif/hubungan antara variabel kecerdasan emosional siswa $\left(\mathrm{x}_{1}\right)$ atau kecerdasan spiritual siswa $\left(\mathrm{X}_{2}\right)$ dengan prestasi belajar Fiqih siswa menggunakan regresi sederhana. 
Sedangkan pengujian hipotesis assosiatif antara variabel emosional siswa $\left(\mathrm{X}_{1}\right)$ dan kecerdasan spiritual siswa $\left(\mathrm{X}_{2}\right)$ secara bersama-sama dengan variabel prestasi belajar Fiqih (hipotesis nomor 3), digunakan regresi ganda.

Persamaan linier regresi sederhana yang digunakan adalah: $Y^{\prime}=a+b X \quad$, Untuk mencari harga $\mathrm{b}$, digunakan rumus:

$$
b=\frac{\sum x y}{\sum x^{2}}=
$$

sedangkan untuk harga harga a, menggunakan rumus:, $\quad a=\bar{Y}-b \bar{X}=$

Untuk mengetahui sumbangan variabel $X_{1}$ atau $X_{2}$ terhadap $Y$ digunakan rumus: $\quad R_{y 1}^{2}=\frac{\left(\sum x_{1} y\right)^{2}}{\sum x_{1}^{2} \sum y^{2}}$

Kemudian, uji signifikansi dapat diketahui dengan rumus: $F=\frac{R K_{\text {reg }}}{R K_{\text {res }}}$ Keterangan:

$\mathrm{F} \quad=\mathrm{Uji} \mathrm{F}(\mathrm{F}$ hitung $)$

$R K_{\text {reg }}=$ Regresi Kuadrat

$R K_{\text {res }}=$ Galat $/$ Res Kuadrat

Hasil atau harga $\mathrm{F}$ hitung, selanjutnya dikonsultasikan dengan $\mathrm{F}$ tabel, dengan taraf kesalahan $5 \%$ maupun $1 \%$. Apabila $\mathrm{F}$ hitung lebih besar dari $\mathrm{F}$ tabel $\left(\mathrm{F}_{\text {hitung }}>\mathrm{F}_{\text {tabel }}\right)$, maka koefisien korelasi yang diuji terdapat hubungan positif dan signifikan antara variabel $\mathrm{X}_{1}$ dengan variabel $\mathrm{Y}$ vatau Variabel $\mathrm{X}_{2}$ dengan Variabel Y. Demikian juga sebaliknya, apabila F hitung lebih kecil dari $\mathrm{F}$ tabel $\left(\mathrm{F}_{\text {hitung }}<\mathrm{F}_{\text {tabel }}\right)$, maka koefisien korelasi yang diuji tidak ada hubungan positif dan signifikan antara variabel $\mathrm{X}_{1}$ dengan variabel $\mathrm{Y}$ atau variabel $\mathrm{X}_{2}$ dengan $\mathrm{Y}$.

Teknik yang digunakan untuk menguji hipotesis no.3, adalah teknik analisis regresi ganda (Multiple regresion), analisis regresi digunakan bila kita ingin mengetahui bagaimana variabel dependen/kriteria dapat diprediksikan melalui variabel independen atau prediktor. Analisis regresi ganda digunakan, bila peneliti bermaksud meramalkan bagaimana keadaan (naik turunnya) variabel dependen (kriterium), bila dua atau lebih variabel independen sebagai faktor prediktor dimanipulasi (dinaik turunkan nilainya). Jadi analisis regresi ganda akan dilakukan bila jumlah variabel independennya minimal. 
Regresi ganda memberi perkiraan nilai Y, bila nilai X1 dan X2 diketahui, dengan rumus: $\quad Y^{\prime}=a=b_{1} X_{1}+b_{2} X_{2}$

Keterangan:

$\mathrm{Y}^{\prime}=$ Nilai $\mathrm{Y}$ yang diprediksikan dari nilai $\mathrm{X} 1$ dan $\mathrm{X} 2$

$\mathrm{a}=$ intersep (nilai $\mathrm{Y}$ bila nilai $\mathrm{X}=0$ )

b1 = slop/regresi (nilai kenaikan/penurunan Y, bila nilai X1 naik satu unit)

b2 = slop/regresi (nilai kenaikan/penurunanY, bila nilai X2 naik satu unit) (Hadjar, 2007).

Untuk mengetahui proporsi sumbangan variabel $X_{1}$ dan $X_{2}$ pada variabel Y digunakan rumus: $R_{y .12}=\frac{J K_{r e g}}{J K^{2}}=$ Sedangkan untuk mengetahui uji signifikansi koefisien korelasi gănda digunakan rumus: $F=\frac{R K_{r e g}}{R K_{r e s}}$ Hasil atau harga $\mathrm{F}$ hitung, selanjutnya dikonsultasikan dengan $\mathrm{F}$ tabel, dengan taraf kesalahan $5 \%$ maupun $1 \%$. Apabila $\mathrm{F}$ hitung lebih besar dari $\mathrm{F}$ tabel $\left(\mathrm{F}_{\text {hitung }}>\right.$ $\left.\mathrm{F}_{\text {tabel}}\right)$, maka koefisien korelasi ganda yang diuji terdapat hubungan positif dan signifikan antara variabel $\mathrm{X}_{1}$ dan $\mathrm{X}_{2}$ secara bersama-sama dengan Variabel $\mathrm{Y}$. Demikian juga sebaliknya, apabila $\mathrm{F}$ hitung lebih kecil dari $\mathrm{F}$ tabel $\left(\mathrm{F}_{\text {hitung }}<\right.$ $\left.\mathrm{F}_{\text {tabel }}\right)$, maka koefisien korelasi ganda yang diuji tidak ada hubungan positif dan signifikan antara variabel $\mathrm{X}_{1}$ dan $\mathrm{X}_{2}$ secara bersama-sama dengan variabel $\mathrm{Y}$.

\section{Hasil Penelitian dan Pembahasan}

\section{Hasil Penelitian}

a. Terdapat hubungan antara Kecerdasan Emocional (EQ) dengan prestasi belajar Fiqih siswa MA NW Keuak

Untuk menguji hipotesis di atas, digunakan perhitungan analisis regresi sederhana $\left(Y^{\prime}=a+b X=\right)$. Sesuai perhitungan analisis regresi sederhana (seperti yang terdapat dalam lampiran) ditemukan harga $\mathrm{a}=56.80$ dan harga $\mathrm{b}$ $=0.20$. Persamaan regresi yang digunakan untuk memprediksi prestasi belajar Fiqih siswa berdasarkan kecerdasan emocional (EQ) siswa adalah $Y^{\prime}=56.80$ $+0.20 \mathrm{X}_{1}$. 
Persamaan regresi dapat digunakan untuk melakukan prediksi seberapa tinggi nilai variabel dependen bila nilai variabel independen dimanipulasi (dirubah-rubah). Artinya untuk setiap kenaikan 1 unit satuan kecerdasan emosional $\left(\mathrm{X}_{1}\right)$ akan diikuti oleh kenaikan secara linier skor/nilai prestasi belajar Fiqih siswa (Y) sebesar 0.20, pada bilangan konstan 56.80. Dengan kata lain, semakin tinggi kecerdasan emosional siswa, maka akan semakin tinggi pula prestasi belajar Fiqih siswa.

Demikian pula sebaliknya, semakin rendah kecerdasan emosional siswa, maka akan semakin rendah pula prestasi beajar Fiqih siswa.

Untuk mengetahui sumbangan pengaruh kecerdasan emosional terhadap prestasi relajar Fiqih siswa digunakan analisis determinasi $\left(\mathrm{R}^{2}\right)$ yang hasilnya dapat dilihat rumus sebagai berikut.

$$
R_{y 1}^{2}=\frac{\left(\sum x_{1} y\right)^{2}}{\sum x_{1}^{2} \sum y^{2}}=\frac{1494791.51}{22506619.45}=0.066=6.6 \%
$$

Berdasarkan hasil perhitungan rumus determinasi tersebut, sumbangan efektif variabel kecerdasan emocional siswa $\left(\mathrm{X}_{1}\right)$ terhadap prestasi belajar Fiqih $(\mathrm{Y})$ diperoleh nilai $=0.066 \mathrm{Hal}$ ini berarti $6.6 \%$ prestasi belajar Fiqih siswa (Y) dipengaruhi oleh Kecerdasan Emosional $\left(\mathrm{X}_{1}\right)$. Artinya bahwa variasi prestasi belajar Fiqih siswa (Y) ditentukan oleh variasi Kecerdasan Emosional $\left(\mathrm{X}_{1}\right)$ sebesar $6.6 \%$, melalui persamaan regresi $\mathrm{Y}=56.80+0.20$ $\mathrm{X}_{1}$. Sisanya sebesar $93.40 \%$ dipengaruhi/ditentukan oleh faktor lain.

Sedangkan untuk menguji signifikansi regresi tersebut digunakan uji $\mathrm{F}$ (F hitung), dengan rum $\mu \mathrm{s}_{=}=\frac{R K_{\text {reg }}}{R K}=\frac{240.44}{58.27}=4.126($ dibulatkan $)=4.13$

Berdasarkan perhitungán rumus $\mathrm{F}_{\mathrm{h}}$ diperoleh harga $\mathrm{F}$ sebesar 4.13 harga ini selanjutnya dikonsultasikan dengan $\mathrm{F}$ tabel $\left(\mathrm{F}_{\mathrm{t}}\right)$, dengan $\mathrm{dk}$ pembilang $=\mathrm{k}$ dan $\mathrm{dk}$ penyebut $=(\mathrm{n}-\mathrm{k}-1)=60-1-1=58$ dan taraf kesalahan yang ditetapkan sebesar $5 \%$. Dalam tabel Ft adalah sebesar 0.047. dalam hal ini berlaku ketentuan "bila $\mathrm{F}_{\mathrm{h}}$ lebih besar dari $\mathrm{F}_{\mathrm{t}}$, maka koefisien korelasi yang diuji adalah signifikan, yaitu dapat diberlakukan untuk seluruh populasi”.

Dari perhitungan di atas, ternyata $\mathrm{F}$ hitung lebih besar dari $\mathrm{F}$ tabel, yaitu $\mathrm{Fh}>\mathrm{Ft}(4.13>0.047)$, maka dapat dinyatakan bahwa regresi sederhana tersebut signifikan dan dapat diberlakukan dimana sampel diambil. 
Berdasarkan tabel di atas diperoleh harga koefisien korelasi variabel kecerdasan emosional $(\mathrm{EQ})$ siswa $\left(\mathrm{X}_{1}\right)$ dengan variabel prestasi belajar Fiqih siswa (Y) sebesar 0.20 , dengan $p=0.047$, yang berarti ada korelasi signifikan antara kecerdasan emosional dengan prestasi belajar Fiqih siswa. Hal ini menunjukkan bahwa alternatif $(\mathrm{Ha})$ yang mengatakan bahwa ada hubungan antara kecerdasan emosional (EQ) dengan prestasi belajar Fiqih siswa diterima dan hipotesis nihil $(\mathrm{Ho})$ yang menyatakan bahwa tidak ada hubungan antara kecerdasan emosional (EQ) dengan prestasi belajar Fiqih siswa ditolak.

Dari tabel anova tersebut, dapat dikatakan bahwa besarnya $F$ regresi dari $F$ hitung $=4.126, \mathrm{~F}$ tabel $=0$ 0.047. maka dapat diperoleh $\mathrm{F}_{\mathrm{h}}>\mathrm{F}_{\mathrm{t}}$ yang menunjukkan bahwa koefisien arah regresi prestasi belajar Fiqih siswa (Y) atas kecerdasan emosional (EQ) $\left(\mathrm{X}_{1}\right)$ signifikan dan linier. Demikian pula dapat dikatakan bahwa dengan mengontrol kecerdasan emosional (EQ) $\left(\mathrm{X}_{1}\right)$ tetap ada kontribusi positif dengan prestasi belajar Fiqih siswa (Y) atau hubungan korelasi parsial.

\section{Terdapat hubungan antara Kecerdasan Spiritual (SQ) dengan prestasi belajar Fiqih siswa MA NW Keruak}

Pengujian hipótesis no. 2 diatas, digunakan perhitungan analisis regresi sederhana ( $Y^{\prime}=a+b X_{2}=$ ), sebagaimana dalam pengujian hipótesis pertama. Sesuai perhitungan analisis regresi sederhana (seperti yang terdapat dalam lampiran) ditemukan harga $a=88.80$ dan harga $b=-0.27$. Persamaan regresi yang digunakan untuk memprediksi prestasi belajar Fiqih siswa berdasarkan kecerdasan spiritual (SQ) siswa adalah $Y^{\prime}=88.80+-0.27 \mathrm{X}_{2}$.

Persamaan regresi dapat digunakan untuk melakukan prediksi seberapa tinggi nilai variabel dependen bila nilai variabel independen dimanipulasi (dirubah-rubah). Artinya untuk setiap kenaikan1 unit satuan kecerdasan spiritual (SQ) $\left(\mathrm{X}_{1}\right)$ akan diikuti oleh kenaikan secara linier skor/nilai prestasi belajar Fiqih siswa (Y) sebesar -0.27, pada bilangan konstan 88.80. Dengan kata lain, semakin tinggi kecerdasan spiritual siswa, maka akan semakin tinggi pula prestasi belajar Fiqih siswa. Demikian pula sebaliknya, semakin rendah 
kecerdasan spiritual siswa, maka akan semakin rendah pula prestasi beajar Fiqih siswa.

Untuk mengetahui sumbangan pengaruh kecerdasan spiritual terhadap prestasi relajar Fiqih siswa digunakan analisis determinasi $\left(\mathrm{R}^{2}\right)$ yang hasilnya

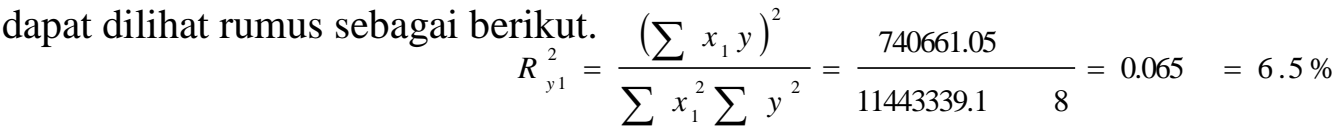

Berdasarkan hasil perhitungan rumus determinasi tersebut, sumbangan efektif variabel kecerdasan spiritual siswa $\left(\mathrm{X}_{2}\right)$ terhadap prestasi belajar Fiqih (Y) diperoleh nilai $=0.065 \mathrm{Hal}$ ini berarti $6.5 \%$ prestasi belajar Fiqih siswa (Y) dipengaruhi oleh Kecerdasan Spiritual siswa $\left(\mathrm{X}_{2}\right)$. Artinya bahwa variasi prestasi belajar Fiqih siswa (Y) ditentukan oleh variasi Kecerdasan Spiritual siswa $\left(\mathrm{X}_{2}\right)$ sebesar $6.5 \%$, melalui persamaan regresi $\mathrm{Y}=88.80+-0.027 \mathrm{X}_{2}$. Sisanya sebesar $93.50 \%$ dipengaruhi/ditentukan oleh faktor lain.

Sedangkan untuk menguji signifikansi regresi tersebut digunakan uji $\mathrm{F}$ (F hitung), dengan rumus $F=\frac{R K_{\text {reg }}}{R K}=\frac{234.31}{58.38}=4.01$

Berdasarkan perhitungan reumus $\mathrm{F}_{\mathrm{h}}^{38}$ diperoleh harga $\mathrm{F}$ sebesar 4.01 harga ini selanjutnya dikonsultasikan dengan $\mathrm{F}$ tabel $\left(\mathrm{F}_{\mathrm{t}}\right)$, dengan $\mathrm{dk}$ pembilang $=\mathrm{k}$ dan $\mathrm{dk}$ penyebut $=(\mathrm{n}-\mathrm{k}-1)=60-1-1=58$ dan taraf kesalahan yang ditetapkan sebesar $5 \%$. Dalam tabel Ft adalah sebesar 0.050. dalam hal ini berlaku ketentuan "bila $F_{h}$ lebih besar dari $F_{t}$, maka koefisien korelasi yang diuji adalah signifikan, yaitu dapat diberlakukan untuk seluruh populasi”.

Dari perhitungan di atas, ternyata $\mathrm{F}$ hitung lebih besar dari $\mathrm{F}$ tabel, yaitu $\mathrm{Fh}>\mathrm{Ft}(4.01>0.050)$, maka dapat dinyatakan bahwa regresi sederhana tersebut signifikan dan dapat diberlakukan dimana sampel diambil.

Berdasarkan tabel di atas diperoleh harga koefisien korelasi variabel kecerdasan spiritual (SQ) siswa $\left(\mathrm{X}_{2}\right)$ dengan variabel prestasi belajar Fiqih siswa (Y) sebesar -0.27 , dengan $p=0.050$, yang berarti ada korelasi signifikan antara kecerdasan spiritual dengan prestasi belajar Fiqih siswa. Hal ini menunjukkan bahwa alternatif ( $\mathrm{Ha}$ ) yang mengatakan bahwa ada hubungan antara kecerdasan spiritual (SQ) dengan prestasi belajar Fiqih siswa diterima 
dan hipotesis nihil $(\mathrm{Ho})$ yang menyatakan bahwa tidak ada hubungan antara kecerdasan spiritual (SQ) dengan prestasi belajar Fiqih siswa ditolak.

Dari tabel anova tersebut, dapat dikatakan bahwa besarnya $\mathrm{F}$ regresi dari $\mathrm{F}$ hitung $=4.014, \mathrm{~F}$ tabel $=0.050$. maka dapat diperoleh $\mathrm{F}_{\mathrm{h}}>\mathrm{F}_{\mathrm{t}}$ yang menunjukkan bahwa koefisien arah regresi prestasi belajar Fiqih siswa (Y) atas kecerdasan spiritual (SQ) $\left(\mathrm{X}_{2}\right)$ signifikan dan linier. Demikian pula dapat dikatakan bahwa dengan mengontrol kecerdasan spiritual (SQ) $\left(\mathrm{X}_{2}\right)$ tetap ada kontribusi positif dengan prestasi belajar Fiqih siswa (Y) atau hubungan korelasi parsial.

\section{Terdapat hubungan antara Kecerdasan Emocional (EQ) dengan} Kecerdasan Spiritual secara bersama-sama terhadap prestasi belajar Fiqih siswa MA NW Keruak

Untuk menguji hipotesis di atas, analisis yang digunakan adalah digunakan analisis regresi ganda dengan rumus $Y^{\prime}=a+b_{1} X_{1}+b_{2} X_{2}$.

Berdasarkan perhitungan (seperti yang terdapat dalam lampiran) ditemukan harga $a=73.06$, harga $b 1=0.23$, dan harga $b 2=-0.27$. Jadi persamaan regresinya adalah $Y^{\prime}=73.06+0.23 \mathrm{X}_{1}+(-0.27) \mathrm{X}_{2}$. Artinya untuk setiap kenaikan 1 unit satuan kecerdasan emosional siswa $\left(\mathrm{X}_{1}\right)$ dan kecerdasan spiritual siswa $\left(\mathrm{X}_{2}\right)$ akan diikuti kenaikan prestasi belajar Fiqih siswa (Y) sebesar 0.23 pada variabel kecerdasan emosional siswa dan -0.27 pada variabel kecerdasan spiritual siswa $\left(\mathrm{X}_{2}\right)$ pada bilangan konstan 73.06. Dengan kata lain, bahwa dalam penelitian ini terbukti semakin tinggi kecerdasan emosional siswa dan kecerdasan spiritual siswa secara bersama-sama, maka akan semakin tinggi pula prestasi belajar Fiqih siswa.

Untuk mengetahui sumbangan pengaruh kecerdasan emosional dan kecerdasan spiritual secara bersama-sama terhadap prestasi belajar Fiqih siswa digunakan analisis determinasi $\left(\mathrm{R}^{2}\right)$ yang hasilnya dapat dilihat rumus sebagai berikut.

$$
R_{y .12}^{2}=\frac{J K_{r e g}}{J K_{\text {tot }}}=\left\lceil\frac{526.444}{3867.933}\right\rceil=0.136=13.6 \%
$$


Jadi terdapat korelasi positif antara kecerdasan emosional dan kecerdasan spiritual secara bersama-sama dengan prestasi belajar Fiqih siswa sebesar 0.136. apakah koefisien korelasi itu dapat digeneralisasikan atau tidak, maka harus diuji signifikansi dengan rumus $\mathrm{F}_{\mathrm{h}}$. Seperti halnya rumus berikut: $F=\frac{R K_{\text {reg }}}{R K_{\text {res }}}=\frac{263.222}{58.623}=4.490$ Berdasarkan perhitungan rumus $\mathrm{F}_{\mathrm{h}}$ (perhitungan selengkapnya sebagaimana dalam lampiran) diperoleh harga $\mathrm{F}$ sebesar 4.490 harga ini selanjutnya dikonsultasikan dengan $F$ tabel $\left(F_{t}\right)$, dengan dk pembilang $=\mathrm{k}$ dan $\mathrm{dk}$ penyebut $=(\mathrm{n}-\mathrm{k}-1)$ dan taraf kesalahan yang ditetapkan sebesar $5 \%$. Dalam tabel Ft adalah sebesar 0.015. dalam hal ini berlaku ketentuan "bila $\mathrm{F}_{\mathrm{h}}$ lebih besar dari $\mathrm{F}_{\mathrm{t}}$, maka koefisien korelasi ganda yang diuji adalah signifikan, yaitu dapat diberlakukan untuk seluruh populasi”.

Dari perhitungan di atas, ternyata $\mathrm{F}$ hitung lebih besar dari $\mathrm{F}$ tabel, yaitu Fh > Ft $(4.490>0.015)$, maka dapat dinyatakan bahwa korelasi ganda tersebut signifikan dan dapat diberlakukan dimana sampel diambil.

Berdasarkan hasil analisis regresi ganda sebagaimana tersebut dalam tabel di atas, diperoleh $F_{\text {hitung }}=4.490$, dengan tingkat signifikansi 0.05. karena probabilitas $(\mathrm{p})=0.015$ lebih kecil dari 0.05 berarti ada korelasi yang sangat signifikan antara kecerdasan emosional $\left(\mathrm{X}_{1}\right)$ dan kecerdasan spiritual $\left(\mathrm{X}_{2}\right)$ secara bersama-sama dengan prestasi belajar Fiqih siswa (Y). Hal ini menunjukkan bahwa secara bersama-sama antara kecerdasan emosional $\left(\mathrm{X}_{1}\right)$ dan kecerdasan spiritual $\left(\mathrm{X}_{2}\right)$ berhubungan dengan prestasi belajar Fiqih siswa $(\mathrm{Y})$. Sehingga hipotesis alternatif yang berupa ada hubungan antara kecerdasan emosional siswa $\left(\mathrm{X}_{1}\right)$ dan kecerdasan spiritual $\left(\mathrm{X}_{2}\right)$ secara bersama-sama terhadap prestasi belajar Fiqih siswa (Y) diterima dan hipotesis nihil (Ho) ditolak. Atau hipotesis telah teruji/terbukti, dengan kata lain terdapat hubungan posoitif antara kecerdasan emosional siswa/EQ $\left(\mathrm{X}_{1}\right)$ dan kecerdasan spiritual siswa/SQ $\left(\mathrm{X}_{2}\right)$, secara bersama-sama dengan prestasi belajar Fiqih siswa (Y) MA NW Keruak.. 


\section{DAFTAR PUSTAKA}

Ary Ginanjar Agustian, Rahasia Sukses Membangun Kecerdasan Emosi dan Spiritual ESQ Emotional Spiritual Quotient Berdasarkan 6 Rukun Iman dan 5 Rukun Islam, (Jakarta : Arga Wijaya Persada, 2001).

Danah Zohar \& Ian Marshall, 2000, SQ: Memanfaatkan Kecerdasan Spiritual dalam Berpikir Integralistik dan Holistik untuk Memaknai Kehidupan, (Bandung : Mizan Media Utama.

Departemen Agama, 2000, Al Qur'an \& Terjemahannya, Semarang : CV. Toha Putra.

Echol, M Jhon dan Hasan Sadily, 1992, Kamus Inggris-Indonesia, Jakarta: Gramedia.

Goleman, Daniel. 2000. Emitional Intelligence (terjemahan). Jakata : PT Gramedia Pustaka Utama.

Gottman, John. 2001. Kiat-kiat Membesarkan Anak yang Memiliki Kecerdasan Emosional (terjemahan). Jakarta : PT Gramedia Pustaka Utama.

Irwanto. 1997. Psikologi Umum. Jakarta : PT. Gramedia Pustaka Utama.

M. Hafidz Anshori, 1995, Kamus Psikologi, Surabaya : Usaha Kanisius.

Murjono, 1996, Pengantar Umum Psikologi, Cet. VII. Jakarta: Bulan Bintang.

Shapiro, Lawrence E, 1997, Mengerjakan Emosional Intelligence pada Anak, Jakarta: Gramedia Pustaka.

Sia, Tjundjing. 2001. Hubungan Antara IQ, EQ, dan QA dengan Prestasi Studi Pada Siswa SMU. Jurnal Anima Vol.17 no.1

2001. Hubungan Antara IQ, EQ, dan QA dengan Prestasi Studi Pada Siswa SMU. Jurnal Anima Vol.17 no.1

Sukidi, 2002, Rahasia Sukses Hidup Bahagia, Kecerdasan Spiritual, Mengapa SQ Lebih Penting Daripada IQ \& SQ, Jakarta: PT. Gramedia Pustaka Umum.

Tasmara, 2001, Toto Tasmara, 2001, Kecerdasan Ruhaniyah : Transendental Intelligence, Jakarta: Gema Insani Press.

Taufiq Pasiak, 2002, Revolusi IQ / EQ /SQ Antara Neurosains dan Al-Qur'an, .(Bandung: Mizan Pustaka.

Winkel, WS 1997. Psikologi Pendidikan dan Evaluasi Belajar. Jakarta : Gramedia. 